\title{
Investigation of associated factors with post-operative outcomes in patients undergoing Tetralogy of Fallot correction
}

\author{
Ahmad Ali Amirghofran', Jamshid Badr ${ }^{2}$ and Mansour Jannati ${ }^{3^{*}}$
}

\begin{abstract}
Background: Tetralogy of Fallot (TOF) is one of the congenital cardiac abnormality which occurs during embryonic time. Although surgical correction, especially early operation, is the best way to treat patients, still contributing factors in morbidity and mortality is controversial. The objective of this study is to investigate potential factors which might be correlated with post-operative outcomes of TOF.

Methods: In this retrospective study, 349 monitored patients with TOF correction were selected. Median of age was $4(0.66-8)$ year, $58 \%$ of patients were male and $42 \%$ were female. Time of inotropic drug, extubation time, and ICU stay were considered as post-operative outcomes which extension of each of them increased the risk of death.

Results: Ventricular septal defect enlargement was associated with longer extubation time and ICU stay. Higher ratio of pre-operative haematocrit was correlated with mortality (0.047).

Conclusions: Results of this study demonstrated that haematocrit ratio before operation should be considered as a predictive factor, and patients with higher ratio of haematocrit require more care after operation. VSD enlargement is associated with longer extubation time and ICU stay.
\end{abstract}

Keywords: Tetralogy of Fallot, Mortality, ICU Stay, Extubation, Haematocrit

\section{Background}

Tetralogy of Fallot (TOF) is a cardiac abnormality that occurs during embryogenesis $[1,2]$. TOF has been known as one of the most common causes of cyanotic heart disease during first ages of life with probability of occurs of 3 in every 10,000 live births which approximately include $7 \%-$ $10 \%$ of all congenital defects [3]. The risk of death in the first year of life is very high, after the first year is constant until age 25 years, and then increases [4]. Four distinct anatomic features which characterize TOF include: (1) overriding aortic root, (2) pulmonary outflow tract obstruction, (3) ventricular septal defect (VSD), and (4) right ventricular hypertrophy (which occurs as result of the obstruction to pulmonary blood flow) [5].TOF is a multifactorial disease and its etiology has been associated with various factors such as maternal intake of retinoic acid, untreated maternal diabetes and chromosomal anomalies [3]. Also, JAG1

\footnotetext{
* Correspondence: janatim@sums.ac.ir

${ }^{3}$ Department of Cardiovascular surgery, Faghihi Hospital, Shiraz University of Medical Sciences, Shiraz, Iran

Full list of author information is available at the end of the article
}

mutations in Alagille syndrome has been associated with TOF [6] Surgically untreated patients are in danger of the death due to hypoxic spells (main cause), cerebrovascular accidents, and brain abscesses [7].

During last century, surgical methods have developed to correct TOF [5]. The early attempts at correction of TOF were followed with high rate of mortality in young children that propelled surgeons to perform surgical treatments in two steps: a shunt operation within the first 2 or 3 years followed by complete cardiopulmonary bypass correction in older ages [8]. The ideal age for correction of children with cyanotic TOF has recently been a controversial topic. These argument totally consider the rate of morbidity and mortality regarding various ages of operation and the correlation between early operation and normal development of the heart and lungs after correction [9-13]. A number of evidences demonstrated that early TOF correction reduces the side effects on vital organs, including the heart itself which can suffer from hypoxemia, and enhances survival and physiological result [13-15]. Generally, the rate of morbidity 
and mortality after operation has been considered to be reduced by increasing the size of patient $[10,13]$, however, TOF correction in the first year of life can support medical benefits, economic and psycho-social advantages [16].

Early correction of TOF can be along with trans- and post-operative matters; for example, complete repair in young age requires utilization of transannular patching (TAP) $[17,18]$. Likely, increase in the need for a transannular patching might compromise right ventricular function in the late postoperative period [11]. On the other hand, implanting a transannular patch can be a significant risk factor for children with a body surface area less than $0.48 \mathrm{~m}^{2}$ [12]. Moreover, the type of repair can impress the right ventricle outflow tract and its function in the late postoperative period $[19,20]$. The late one is particularly important in the cases of correction in the first year of life, because of more frequent use of transannular patches in this group of patients.

Regarding absence of consensus about the best time of correction and the best type of repair, the objective of this study is to investigate the effective pre-, tans-, and post-operative factors with respect to mortality and morbidity outcomes in TOF patients that can be used as helpful surgical pre-considerations.

\section{Methods}

\section{Patients}

This retrospective study was performed on 382 patients with Tetralogy of Fallot who undertook correction surgery from 2001 to 2010 in three heart centres in Shiraz.

\section{Inclusion and exclusion criteria}

Thirty three patients who had either of homograft utilization, or re-operation, or only BT shunt (BlalockThomas-Taussig shunt) were removed from study and the rest 349 with complete correction were entered into study.

\section{Performance}

Information of each patient was recorded on separate form for statistical analysis as following: Demographic information including age, gender, weight, HCT, type of surgery, previous surgery. Trans-operative information including pump time, Ventricular Septal Defect (VSD) enlargement, transannular patching, monocusp utilization, PA/RV gradient, operation approach. Post-operative information including inotrope time, extubation time, length of ICU stay, and post-operative side effects including heart block, bleeding and death.

\section{Ethical consideration}

The study was carried out in accordance with the Declaration of Helsinki, and the ethics committee of the Shiraz University of Medical Sciences approved the protocols of the study. The patients' records were kept confidential.

\section{Data analysis}

Qualitative and quantitative data were reported as frequency (\%) and median (range), respectively. Statistical analysis was performed using Chi-square, t-test, multiple regression and logistic regression, and $P$ value $<0.05$ was considered significant. All data were analyzed with IBM SPSS Statistics for Windows, version 18.0 (SPSS Inc., Chicago, Illinois, USA).

\section{Results}

Of 382 patients, those homograft was used for them, or underwent redo surgery, or just had BT Shunt Surgery were excluded and demographic information of 349 patients with tetralogy of fallot on whom complete correction was performed has been presented in Table 1. This information include pre-, trans-, and post-operative characteristics of patients under study.

Statistical analysis in order to find any correlation between post-operative and pre/trans operative variables showed that previous operation reduce the length of ICU stay and extubation time. Also, occurrence of VSD enlargement is in direct relation with inotrope time, ICU stay, and extubation time. Moreover, the increasing

Table 1 Pre-, trans-, and post-operative characteristics of patients ${ }^{a}$

\begin{tabular}{|c|c|}
\hline Variable & Value \\
\hline \multicolumn{2}{|l|}{ Pre-operative } \\
\hline Age, year & $4(0.66-8)$ \\
\hline \multicolumn{2}{|l|}{ Gender } \\
\hline Male & $204(58)$ \\
\hline Female & $145(42)$ \\
\hline Weight, Kg & $6(4-7)$ \\
\hline Previous operation & $90(25.8)$ \\
\hline Haematocrit $(\mathrm{HCT}), \%$ & $48(11.5-77.8)$ \\
\hline \multicolumn{2}{|l|}{ Trans-operative } \\
\hline Pump time, min & $79(24-280)$ \\
\hline VSD Enlargement & $133(38.1)$ \\
\hline Transannular patching & $158(45.3)$ \\
\hline Pulmonary monocusp & $40(11.5)$ \\
\hline Transatrial Myectomy & $77(22.1)$ \\
\hline RV-LV Ratio & $60(10-137)$ \\
\hline RV-PA-Gradiant, mmHg & $20(0-84)$ \\
\hline \multicolumn{2}{|l|}{ Post-operative } \\
\hline Time of inotropic drug, hrs & $46(0-360)$ \\
\hline Extubation time, hrs & $8(0-211)$ \\
\hline ICU-stay, day & $3(1-69)$ \\
\hline Bleeding to operation & $17(4.9)$ \\
\hline Heart block & $11(3.2)$ \\
\hline Post operation mortality & $15(4.3)$ \\
\hline
\end{tabular}

${ }^{\mathrm{a}}$ Data are presented as Median (range) and No. (\%) 
length of inotrope time increases the mortality risk. In a same way, increasing length of extubation time increases the risk of bleeding (Table 2).

In order to make a more accurate knowledge about the correlation between post-operative and pre/trans operative variables, regression analysis was performed on data (Table 3). The results showed that there is a correlation inotrope time and dead and Pump time. Pump time, RV-LV Ratio, bleeding, and dead have correlation with Extubation time.

As presented in Table 4, there is a statistical significant relation between the pump time and mortality; the longer pump time, and the higher probability of death. Likewise, the higher percentage of HCT significantly increase the risk of mortality.

\section{Discussion}

Tetrallogy of fallot is the oldest surgically treated congenital heart disease which is well documented due to many studies have been done around it in long-term [21]. Nonetheless, post-operative morbidity and mortality are of main concerns in regard with TOF surgically treatment. Recently, nuclear magnetic resonance has being valuably contributed to evaluate cardiac function to postoperative follow-ups of patients with tetralogy of Fallot [22] and predicts exercise capacity in adult operated tetralogy of Fallot [23]. In this regard, older age at operation, previous heart failure, and high $>0.5 \mathrm{RV}: \mathrm{LV}$ systolic pressure are considered predictors of late mortality [24]. In this study, we investigated other potential factors which might correlate with post-operative outcomes.

Early correction of TOF has been suggested as the best solution, as it decrease the rate of morbidity and mortality and low incidence of transannular patching [25]. According to our results the age of patients who died were less than whom survived; however this difference was not significant. Monocusp valves replacement has been reported to operate effectively in the early postoperative period, although there are concerns about the long-term efficiency of monocusp. Totally, no significant correlation was observed between monocusp pulmonary replacement and post-operative outcomes of correction [26-28]. Similarly, in the present study, pulmonary monocusp replacement was not associated with postoperative outcomes. In a study conducted on 80 patient in Pakistan, there was no significant statistical relation between heart block and different types of patching, however, it was demonstrated that transannular patching trigger to bleeding and as result reoperation of patients $(P=0.001)$ [29]. In our study, on the other hand, heart block was not significantly correlated with post-operative outcomes.

The transatrial and transatrial-transpulmonary approach is frequently used today in all age groups, including neonates, with survival rate close to $100 \%$ and a low incidence of early reintervention [25, 30, 31]. Stewart et al. [32] reviewed 102 patients (median age 5.9 months) comparing transatrial approaches with TAP. They found that postoperative RV outflow tract gradients were greater in the transatrial and transatrial-transpulmonary groups than in the Transannular patching group. In present study, no correlation was found between approach of operation and neither of ventricular outflow or morbidity outcomes.

Logistic regression analysis showed that bleeding incidence correlates with death outcome. Also, According to mortality analysis of present study, duration of pump time in dead patients was significantly longer compare with survived patients. Likewise, the percentage of HCT before surgery in cases with death outcome was higher than those survived (0.047). In a same way, Guevara et al. showed that preoperative haematocrit showed statistically significant association with 30-day mortality [33]. Actually haematocrit increases in TOF patients as a response to hypoxia [34]. However, in another study it was demonstrated that the haematocrit level did not correlate with mortality [35].

Regarding the ICU stay outcome, patient who had carried out previous operation required shorter ICU stay. In other words, previous operation shorten the length of ICU stay. Also, increase of VSD enlargement significantly increased

Table 2 Correlation of post-operative variables with pre- and trans-operative ones ${ }^{\mathrm{a}}$

\begin{tabular}{|c|c|c|c|c|c|c|c|c|c|}
\hline & \multicolumn{3}{|c|}{ Time of inotropic drug } & \multicolumn{3}{|l|}{ ICU stay } & \multicolumn{3}{|c|}{ Extubation time } \\
\hline & Yes & No & $P$-value & Yes & No & $P$-value & Yes & No & $P$-value \\
\hline Previous Operation & $49.3 \pm 27.7$ & $53.54 \pm 36.5$ & 0.307 & $3.4 \pm 2.2$ & $4.8 \pm 7.9$ & 0.013 & $8.2 \pm 6.4$ & $14.7 \pm 25.6$ & $\leq 0.001$ \\
\hline VSD Enlargement & $57.34 \pm 49.27$ & $49.67 \pm 20.45$ & 0.098 & $5.5 \pm 7.7$ & $3.8 \pm 6.4$ & 0.033 & $17.5 \pm 32$ & $10.5 \pm 11.5$ & 0.024 \\
\hline Heart block & $47.44 \pm 20.6$ & $52.7 \pm 34.9$ & 0.652 & $3.5 \pm 1.9$ & $4.5 \pm 7.1$ & & $15.3 \pm 14.6$ & $13.1 \pm 22.8$ & 0.676 \\
\hline Pulmonary-monocusp & $66.85 \pm 74.42$ & $50.33 \pm 25.62$ & 0.21 & - & - & - & - & - & - \\
\hline Transatrial Myectomy & $48.2 \pm 22.6$ & $53.6 \pm 37.22$ & 0.12 & - & - & - & - & - & - \\
\hline Transannular Patch (TAP) & & & & $4.7 \pm 6.7$ & $4.3 \pm 7.3$ & 0.606 & $15.5 \pm 30.2$ & $11.3 \pm 12.8$ & 0.113 \\
\hline Bleeding & & & & $5.2 \pm 2.2$ & $4.4 \pm 7.1$ & 0.681 & $46 \pm 77.3$ & $11.8 \pm 16.6$ & 0.014 \\
\hline Dead & $70 \pm 97.16$ & $52 \pm 31.8$ & 0.014 & - & - & - & $102.4 \pm 100$ & $11.7 \pm 16.2$ & $\leq 0.001$ \\
\hline
\end{tabular}

${ }^{\mathrm{a}}$ Data are presented as Mean \pm standard deviation 
Table 3 Regression analysis between post-operative independent variables and pre/trans-operative variables ${ }^{a}$

\begin{tabular}{|c|c|c|c|c|c|c|c|c|}
\hline & \multicolumn{2}{|c|}{ Time of inotropic drug ${ }^{b}$} & \multicolumn{2}{|c|}{ Extubation time $^{b}$} & \multicolumn{2}{|l|}{ ICU-stay $^{\mathrm{b}}$} & \multicolumn{2}{|l|}{ Death $^{c}$} \\
\hline & B coefficient & $P$-value & B coefficient & $P$-value & B coefficient & $P$-value & B coefficient & $P$-value \\
\hline Age & 0.072 & 0.198 & -0.142 & 0.011 & -0.099 & 0.072 & -0.047 & 0.377 \\
\hline Previous operation & -0.061 & 0.399 & -0.079 & 0.12 & -0.005 & 0.943 & -0.133 & 0.93 \\
\hline $\mathrm{HCT}$ & 0.019 & 0.795 & -0.069 & 0.172 & -0.179 & 0.021 & 0.096 & 0.182 \\
\hline Transatrial myectomy & 0.031 & 0.680 & -0.029 & 0.581 & 0.117 & 0.14 & & - \\
\hline pulmonary monocusp & 0.046 & 0.582 & -0.065 & 0.325 & 0.021 & 0.807 & & - \\
\hline Pump time & 0.18 & 0.015 & 0.259 & $\leq 0.001$ & 0.072 & 0.358 & & - \\
\hline VSD Enlargement & 0.008 & 0.907 & 0.003 & 0.946 & 0.069 & 0.355 & 0.084 & 0.959 \\
\hline Transannular patching & -0.037 & 0.675 & 0.046 & 0.448 & -0.023 & 0.8 & -0.052 & 0.596 \\
\hline RV-LV Ratio & 0.109 & 0.208 & 0.118 & 0.05 & 0.101 & 0.268 & 0.044 & 0.339 \\
\hline RV-LV Grad & -0.065 & 0.446 & - & - & - & - & & - \\
\hline Heart block & -0.053 & 0.433 & 0.020 & 0.68 & -0.025 & 0.73 & -2.77 & 0.212 \\
\hline bleeding & 0.091 & 0.252 & 0.138 & 0.009 & -0.005 & 0.952 & -4.8 & 0.003 \\
\hline Dead & 0.332 & $\leq 0.001$ & 0.65 & $\leq 0.001$ & 0.172 & 0.028 & & - \\
\hline
\end{tabular}

${ }^{\mathrm{a}}$ Data are presented as regression $P$-value between two distinct variable

${ }^{\mathrm{b}}$ Multiple regression analysis

${ }^{c}$ Logistic regression analysis

the length of ICU stay. Lee et al. demonstrated that patients who underwent early repair for TOF showed more VSD closure and longer ICU stay, although they did not indicate the correlation between these two factors [36]. Moreover, multiple regression analysis demonstrated that haematocrit ratio indirectly and dead outcome directly correlate with length of ICU stay. Similar to our findings, Benbrik eat al. demonstrated that patient with higher level of haematocrit undertook shorter period of ICU stay [35]. Based on our results, increasing the length of inotrope time was correlated with dead outcome. This correlation was also confirmed by multiple linear regression analysis $(P<0.001)$. However, it has been shown that patients with less time of inotropic drug exhibited similar mortality rate compare with patients who underwent longer time of inotropic drug [35].

The average of extubation time among patients with previous operation background was more than those without previous experience. Also, incidence of VSD enlargement and bleeding were significantly in relation with increase of extubation time. However, some studies have not shown any relation between extubation time and VSD [37]. In addition, those patients with dead outcome has showed longer extubation time. The results of multiple

Table 4 Mortality dependence to some independent variables ${ }^{a}$

\begin{tabular}{llll}
\hline & Dead & Alive & $P$-Value \\
\hline Age & $4.9 \pm 5.5$ & $6.5 \pm 6.9$ & 0.37 \\
Pump-time, hr & $119 \pm 67.7$ & $80.8 \pm 25.2$ & 0.047 \\
RV-LV Ratio & $64.7 \pm 9.8$ & $62 \pm 18.6$ & 0.363 \\
HCT, \% & $59.9 \pm 10.5$ & $48.6 \pm 10.5$ & 0.047 \\
\hline
\end{tabular}

${ }^{\mathrm{a}}$ Data are presented as Mean \pm standard deviation regression also demonstrated that extubation time directly correlates with pump time and RV-LV ratio, along with bleeding and dead. Although our results indicated to the significance of RV-LV ratio, other studies did not show RV-LV ratio as a significant factor which can be different in relation with different variables [38].

\section{Conclusion}

In conclusion, results of this study demonstrated that haematocrit ratio before operation should be considered as a predictive factor, and patients with higher ratio of haematocrit require more care after operation. VSD enlargement is associated with longer extubation time and ICU stay. Also, longer time of inotropic drug, extubation time, and ICU stay are threatening and alerting the incidence of death. Thus, extension of each of these factors should be paid more attention.

\section{Abbreviations}

HCT: Hematocrit; ICU: Intensive care unit; LV: Left ventricular; RV: Right ventricular; TAP: Transannular patch; TOF: Tetralogy of fallot; VSD: Ventricular septal defect

\section{Acknowledgements}

There is no acknowledgment for the present study.

Funding

There is no funding for the present study.

\section{Availability of data and materials}

The datasets used and/or analysed during the current study are available from the corresponding author on reasonable request.

\section{Authors' contributions}

Conception and design: AAA, and MJ; Analysis and interpretation: JB; Data collection: JB, and MJ; Writing the article: MJ, and AAA; Critical revision of the article: AAA, JB, and MJ; Statistical analysis: JB. All authors read and approved the final manuscript. 


\section{Ethics approval and consent to participate}

Retrospective data analysis was approved by the review board of the ethics committee of the Shiraz University of Medical Sciences.

\section{Consent for publication}

Not applicable.

\section{Competing interests}

The authors declare that they have no competing interests.

\section{Publisher's Note}

Springer Nature remains neutral with regard to jurisdictional claims in published maps and institutional affiliations.

\section{Author details}

${ }^{1}$ Associated Professor, Shiraz University of Medical Sciences, Shiraz, Iran. ${ }^{2}$ Cardiovascular Surgeon, Shiraz University of Medical Sciences, Shiraz, Iran. ${ }^{3}$ Department of Cardiovascular surgery, Faghihi Hospital, Shiraz University of Medical Sciences, Shiraz, Iran.

Received: 13 September 2017 Accepted: 16 January 2018

Published online: 15 March 2018

\section{References}

1. Van Praagh R. The first Stella van Praagh memorial lecture: the history and anatomy of tetralogy of Fallot. Semin Thorac Cardiovasc Surg Pediatr Card Surg Annu. 2009:19-38. https://doi.org/10.1053/j.pcsu.2009.01.004 www.ncbi. nlm.nih.gov/pubmed/19349011

2. Anderson RH, Jacobs ML. The anatomy of tetralogy of Fallot with pulmonary stenosis. Cardiol Young. 2008;18(Suppl 3):12-21. http://dx.doi, org/10.1017/S1047951108003259 www.ncbi.nlm.nih.gov/pubmed/19094375

3. Bailliard F, Anderson RH. Tetralogy of Fallot. Orphanet J Rare Dis. 2009;4:2. http:// dx.doi.org/10.1186/1750-1172-4-2 www.ncbin.nlm.nih.gov/pubmed/19144126

4. Kouchoukos N. Ventricular septal defect with pulmonary stenosis or atresia. Cardiac surgery: morphology, diagnostic criteria, natural history, techniques, results and indications. 2003.

5. Starr JP. Tetralogy of fallot: yesterday and today. World J Surg. 2010;34:65868. http://dx.doi.org/10.1007/s00268-009-0296-8 www.ncbi.nlm.nih.gov/ pubmed/20091166

6. McElhinney DB, Krantz ID, Bason L, Piccoli DA, Emerick KM, Spinner NB, et al. Analysis of cardiovascular phenotype and genotype-phenotype correlation in individuals with a JAG1 mutation and/or Alagille syndrome. Circulation. 2002;106:2567-74. www.ncbi.nlm.nih.gov/pubmed/12427653

7. Loh TF, Ang YH, Wong YK, Tan HY. Fallot's tetralogy-natural history. Singap Med J. 1973;14:169-71. www.ncbi.nlm.nih.gov/pubmed/4777845

8. Kirklin JW, Barratt-Boyes BG. Tetralogy of Fallot with pulmonary stenosis. In: Kirklin JW, Barratt-Boyes BG, editors. Cardiac surgery. New York: Churchill Livingstone; 1993. p. 863-942.

9. Reddy VM, Liddicoat JR, McElhinney DB, Brook MM, Stanger P, Hanley FL. Routine primary repair of tetralogy of Fallot in neonates and infants less than three months of age. Ann Thorac Surg. 1995;60:S592-6. www.ncbi.nIm. nih.gov/pubmed/8604943

10. Hennein HA, Mosca RS, Urcelay G, Crowley DC, Bove EL. Intermediate results after complete repair of tetralogy of Fallot in neonates. J Thorac Cardiovasc Surg. 1995;109:332-42. 44; discussion 342-3. http://dx.doi.org/10.1016/S00225223(95)70395-0 www.ncbi.nlm.nih.gov/pubmed/7531798

11. Vobecky SJ, Williams WG, Trusler GA, Coles JG, Rebeyka IM, Smallhorn J, et al. Survival analysis of infants under age 18 months presenting with tetralogy of Fallot. Ann Thorac Surg. 1993;56:944-9. discussion 949-50. www. ncbi.nlm.nih.gov/pubmed/7692831

12. Kirklin JW, Blackstone EH, Pacifico AD, Brown RN, Bargeron LM Jr. Routine primary repair vs two-stage repair of tetralogy of Fallot. Circulation. 1979;60: 373-86. www.ncbi.nlm.nih.gov/pubmed/445756

13. Castaneda AR, Freed MD, Williams RG, Norwood WI. Repair of tetralogy of Fallot in infancy. Early and late results. J Thorac Cardiovasc Surg. 1977;74: 372-81. www.ncbi.nlm.nih.gov/pubmed/895171

14. Castaneda AR, Mayer JE Jr, Jonas RA, Lock JE, Wessel DL, Hickey PR. The neonate with critical congenital heart disease: repair-a surgical challenge. J Thorac Cardiovasc Surg. 1989;98:869-75. www.ncbi.nlm.nih.gov/pubmed/2811420
15. Van Arsdell GS, Maharaj GS, Tom J, Rao VK, Coles JG, Freedom RM, et al. What is the optimal age for repair of tetralogy of Fallot? Circulation. 2000; 102:III123-9. www.ncbi.nlm.nih.gov/pubmed/11082374

16. Moraes Neto FR, Santos CC, Moraes CR. Intracardiac correction of tetralogy of fallot in the first year of life: short-term and mid-term results. Rev Bras Cir Cardiovasc. 2008;23:216-23. www.ncbi.n/m.nih.gov/pubmed/18820785

17. Touati GD, Vouhe PR, Amodeo A, Pouard P, Mauriat P, Leca F, et al. Primary repair of tetralogy of Fallot in infancy. J Thorac Cardiovasc Surg. 1990;99: 396-402. discussion -3. www.ncbi.nlm.nih.gov/pubmed/2308358

18. Gustafson RA, Murray GF, Warden HE, Hill RC, Rozar GE Jr. Early primary repair of tetralogy of Fallot. Ann Thorac Surg. 1988;45:235-41. www.ncbi. nlm.nih.gov/pubmed/3348694

19. Kirklin JK, Kirklin JW, Blackstone EH, Milano A, Pacifico AD. Effect of transannular patching on outcome after repair of tetralogy of Fallot. Ann Thorac Surg. 1989;48:783-91. www.ncbi.nIm.nih.gov/pubmed/2596914

20. Redington AN, Oldershaw PJ, Shinebourne EA, Rigby ML. A new technique for the assessment of pulmonary regurgitation and its application to the assessment of right ventricular function before and after repair of tetralogy of Fallot. Br Heart J. 1988;60:57-65. www.ncbi.nlm.nih.gov/pubmed/3408618

21. Williams RG, Pearson GD, Barst RJ, Child JS, del Nido P, Gersony WM, et al. Report of the National Heart, Lung, and Blood Institute working group on research in adult congenital heart disease. J Am Coll Cardiol. 2006;47:701-7. http://dx.doi.org/ 10.1016/j.jacc.2005.08.074 www.ncbi.nIm.nih.gov/pubmed/16487831

22. Helbing WA, de Roos A. Clinical applications of cardiac magnetic resonance imaging after repair of tetralogy of Fallot. Pediatr Cardiol. 2000;21:70-9. http:// dx.doi.org/10.1007/s002469910009 www.ncbi.nIm.nih.gov/pubmed/10672616

23. Yap J, Tan J, Le T, Gao F, Zhong L, Liew R, et al. Assessment of left ventricular preload by cardiac magnetic resonance imaging predicts exercise capacity in adult operated tetralogy of Fallot: a retrospective study. BMC Cardiovasc Disord. 2014;23:122.

24. Murphy JG, Gersh BJ, Mair DD, Fuster V, McGoon MD, Ilstrup DM, et al. Long-term outcome in patients undergoing surgical repair of tetralogy of Fallot. N Engl J Med. 1993;329:593-9. http://dx.doi.org/10.1056/ NEJM199308263290901 www.ncbi.n/m.nih.gov/pubmed/7688102

25. Parry AJ, McElhinney DB, Kung GC, Reddy VM, Brook MM, Hanley FL. Elective primary repair of acyanotic tetralogy of Fallot in early infancy: overall outcome and impact on the pulmonary valve. J Am Coll Cardiol. 2000;36:2279-83. www.ncbi.nlm.nih.gov/pubmed/11127473

26. Vogt PR, Genoni M, Kunzli A, Turina MI. Cryopreserved homograft monocusp valves for reconstruction of the right ventricular outflow tract. J Thorac Cardiovasc Surg. 1997;113:423. http://dx.doi.org/10.1016/S00225223(97)70345-3 www.ncbi.nlm.nih.gov/pubmed/9040642

27. Bogers AJ, Roofthooft M, Pisters H, Spitaels SE, Bos E. Long-term results of the gamma-irradiation-preserved homograft monocusp for transannular reconstruction of the right-ventricular outflow tract in tetralogy of Fallot. Thorac Cardiovasc Surg. 1994;42:337-9. http://dx.doi.org/10.1055/s-20071016518 www.ncbi.nlm.nih.gov/pubmed/7534953

28. Gundry SR, Razzouk AJ, Boskind JF, Bansal R, Bailey LL. Fate of the pericardial monocusp pulmonary valve for right ventricular outflow tract reconstruction. Early function, late failure without obstruction. J Thorac Cardiovasc Surg. 1994;107:908-12. discussion 12-3. www.ncbi.nlm.nih.gov/ pubmed/8127122

29. Khan I, Tufail Z, Afridi S, labal M, Khan T, Waheed A. Surgery for Tetralogy of Fallot in adults: early outcomes. Braz I Cardiovasc Surg. 2016;31:300-3. http://dx.doi.org/ 10.5935/1678-9741.20160063 www.ncbi.nlm.nih.gov/pubmed/27849302

30. Fraser CD Jr, McKenzie ED, Cooley DA. Tetralogy of Fallot: surgical management individualized to the patient. Ann Thorac Surg. 2001;71:155661. discussion 61-3. www.ncbi.nlm.nih.gov/pubmed/11383800

31. Karl TR, Sano S, Pornviliwan S, Mee RB. Tetralogy of Fallot: favorable outcome of nonneonatal transatrial, transpulmonary repair. Ann Thorac Surg. 1992;54:903-7. www.ncbi.nlm.nih.gov/pubmed/1417283

32. Stewart RD, Backer CL, Young L, Mavroudis C. Tetralogy of Fallot: results of a pulmonary valve-sparing strategy. Ann Thorac Surg. 2005;80:1431-8. discussion 8-9. http://dx.doi.org/10.1016/j.athoracsur.2005.04.016 www.ncbi. nlm.nih.gov/pubmed/16181883

33. Guevara JH, Zorrilla-Vaca A, Silva-Gordillo GC. The utility of preoperative level of erythrocytosis in the prediction of postoperative blood loss and 30-day mortality in patients with tetralogy of fallot. Ann Card Anaesth. 2017;20:188-92. http://dx. doi.org/10.4103/aca.ACA_25_17 www.ncbi.nlm.nih.gov/pubmed/28393779

34. Puspitasari F, Harimurti GM. Hyperviscoucity in cyanotic congenital heart disease. Jurnal Kardiologi Indonesia. 2011;31:41-7. 
35. Benbrik N, Romefort B, Le Gloan L, Warin K, Hauet Q, Guerin P, et al. Late repair of tetralogy of Fallot during childhood in patients from developing countries. Eur J Cardiothorac Surg. 2015;47:e113-7. http:// dx.doi.org/10.1093/ejcts/ezu469 www.ncbi.nlm.nih.gov/pubmed/ 25473030

36. Lee C, Lee CN, Kim SC, Lim C, Chang YH, Kang CH, et al. Outcome after one-stage repair of tetralogy of Fallot. J Cardiovasc Surg. 2006;47: 65-70. www.ncbi.nlm.nih.gov/pubmed/16434948

37. Mahle WT, Jacobs JP, Jacobs ML, Kim S, Kirshbom PM, Pasquali SK, et al. Early Extubation after repair of Tetralogy of Fallot and the Fontan procedure: an analysis of the Society of Thoracic Surgeons congenital heart surgery database. Ann Thorac Surg. 2016;102:850-8. http://dx.doi.org/10. 1016/.j.athoracsur.2016.03.013 www.ncbi.n/m.nih.gov/pubmed/27173073

38. Kumar M, Turrentine MW, Rodefeld MD, Bell T, Brown JW. Right ventricular outflow tract reconstruction with a Polytetrafluoroethylene Monocusp valve: a 20-year experience. Semin Thorac Cardiovasc Surg. 2016;28:463-70. http://dx.doi. org/10.1053/.jsemtcvs.2016.05.003 www.ncbi.nlm.nih.gov/pubmed/28043462

Submit your next manuscript to BioMed Central and we will help you at every step:

- We accept pre-submission inquiries

- Our selector tool helps you to find the most relevant journal

- We provide round the clock customer support

- Convenient online submission

- Thorough peer review

- Inclusion in PubMed and all major indexing services

- Maximum visibility for your research

Submit your manuscript at www.biomedcentral.com/submit
Biomed Central 